\title{
CHALLENGES AND IMPLICATIONS OF EDUCATION SYSTEM IN INDIA
}

\author{
MATHUMITA SUNDARAM \\ B.com (Information systems Management)- $3^{\text {rd }}$ year \\ Student, S.D.N.B. Vaishnav college for women, Chennai, Tamilnadu
}

\begin{abstract}
The Indian education System has its own share of issues and challenges which needs to be solved for betterment and improvement in the system. India has remarkably transformed its higher education landscape, with widespread access of education to all levels of students. This paper focuses on the key challenges and implications in the field of education from the point of view of parents as well as students in India.
\end{abstract}

Keywords: Quality Education, effectiveness, efficiency.

\section{INTRODUCTION:}

Education in India is primarily provided by public and private schools. To know the development in a society, literacy is another proper indicator of economic development. As per population census of India in 2011, the literacy rate of India has shown an improvement of $9.2 \%$. It has gone up to $74.04 \%$ from $65.38 \%$ in 2001 . The nation also suffers from a great gender disparity in literacy rate of $82.14 \%$ for men and $65.46 \%$ for women. The southern state, Kerala has the highest literacy rate of $93.91 \%$ in India and Bihar with a figure of $63.82 \%$ has the lowest literacy rate in India. Today, knowledge is power. The more knowledge one has, the more empowered one is. However, India continues to face stern challenges. Despite growing investment in education, $25 \%$ of its population is still illiterate, only $15 \%$ of Indian students reach high school and just $7 \%$ graduate. Despite these challenges higher education system of India equally have lot of opportunities to overcome these challenges and have the capability to make its identity at the international level. However, it needs more transparency and accountability, the role of universities and colleges in the new millennium and emerging scientific research on how people learn is of utmost important. India provides highly skilled people to other countries Therefore, it is very easy for India to transfer our country from a developing nation to a developed nation. Objective of the study is to analyse the challenges present in the education system. To know the parent- children conception about the system. To know further about the education system in India. Scope of the study is to help the readers to analyse the problems prevalent in the education system in India. It will help us to understand the point of view of the students as well as parents. It also helps in bringing out appropriate solution to the problems. The limitations of this study are, the sample size was 125 respondents. The sample circulation was completed within a short span of time. The results have been declared on the basis of respondents answer, it may be uneven also. If the respondents were even more than the acquired, then the results could have varied.

\section{REVIEW OF LITERATURE}

- Dr. R.N. Nadar, Vice Principal of Guru Nanak college of Arts, Science \& Commerce. He studied the contemporary issues and challenges in the Indian education system. He gave a clear review about the various different curriculum bodies govern the education system in India. He has also discussed about dealing with various aspirations of people in democratic country which itself is a major challenge with solutions.

- K.C Chakrabarty, deputy Governor of the RBI, at the JRE school of management, he has discussed about the issues and challenges prevalent in the Indian education system. He has also provided with the required suggestions to the issues present. He also pestered on the topic of RBI's role and commercial bank's role in the education sector.

\section{RESEARCH METHODOLOGY}

Well-structured questionnaire was framed, and responses were collected through google forms. Secondary data was collected from already existing sources like periodic journals, websites etc....sample size is 125 , where respondents across various places in India. Convenience sampling technique was used. Statistical tools used are percentage analysis and weighted average.

\section{DATA ANALYSIS}


International Advanced Research Journal in Science, Engineering and Technology

Vol. 8, Issue 7, July 2021

DOI: 10.17148/IARJSET.2021.8705

4.1 - Table 1 showing weighted average of challenges persistent in education system in India.

\begin{tabular}{|c|c|c|}
\hline Particulars & Frequency & Percentage \\
\hline Yes & 28 & $22.4 \%$ \\
\hline No & 65 & $52 \%$ \\
\hline Maybe & 32 & $25.6 \%$ \\
\hline tal & 125 & 100 \\
\hline
\end{tabular}

4.2- Table 2 showing the percentage analysis of tuition fees charged by institution is fair or not.

\begin{tabular}{|c|c|c|c|c|c|c|c|c|}
\hline Factors & $\mathbf{5}$ & $\mathbf{4}$ & $\mathbf{3}$ & $\mathbf{2}$ & $\mathbf{1}$ & $\boldsymbol{\Sigma} \boldsymbol{w \boldsymbol { x }}$ & $\begin{array}{l}\boldsymbol{\Sigma} \boldsymbol{w} \boldsymbol{x} \\
/ \boldsymbol{x}\end{array}$ & Rank \\
\hline $\begin{array}{c}\text { Benefits of } \\
\text { extra- } \\
\text { curricular } \\
\text { activities }\end{array}$ & 39 & 37 & 31 & 10 & 8 & 464 & 30.93 & I \\
\hline $\begin{array}{c}\text { Technology } \\
\text { usage by } \\
\text { teachers }\end{array}$ & 17 & 48 & 46 & 12 & 2 & 441 & 29.4 & II \\
\hline $\begin{array}{c}\text { Capacity in } \\
\text { classroom }\end{array}$ & 18 & 30 & 62 & 14 & 1 & 425 & 28.3 & III \\
\hline $\begin{array}{c}\text { Student- } \\
\text { teacher } \\
\text { ratio }\end{array}$ & 14 & 29 & 63 & 14 & 5 & 408 & 27.2 & IV \\
\hline
\end{tabular}

4.3- Table 3 showing the percentage analysis of whether infrastructure facilities are present in schools and colleges.

\begin{tabular}{|c|c|c|}
\hline Particulars & Frequency & Percentage \\
\hline Yes & 65 & $52 \%$ \\
\hline No & 36 & $28.8 \%$ \\
\hline Maybe & 24 & $19.2 \%$ \\
\hline Total & 125 & $100 \%$ \\
\hline
\end{tabular}

4.4- Table 4 showing the percentage analysis of educating children through creative and innovative methods.

\begin{tabular}{|c|c|c|}
\hline Particulars & Frequency & Percentage \\
\hline Yes & 41 & $32.8 \%$ \\
\hline No & 42 & $33.6 \%$ \\
\hline Maybe & 42 & $33.6 \%$ \\
\hline Total & 125 & $100 \%$ \\
\hline
\end{tabular}

4.5 - Table 5 showing the percentage analysis of the quality of education provided to students.

\begin{tabular}{|c|c|c|}
\hline Particulars & Frequency & Percentage \\
\hline Yes & $\mathbf{5 4}$ & $\mathbf{4 3 . 2 \%}$ \\
\hline No & 36 & $\mathbf{2 8 . 8 \%}$ \\
\hline Maybe & 35 & $\mathbf{2 8 \%}$ \\
\hline Total & $\mathbf{1 2 5}$ & $\mathbf{1 0 0 \%}$ \\
\hline
\end{tabular}

4.6 - Table 6 shows the percentage analysis of teaching methods being updated in educational institutions. 
International Advanced Research Journal in Science, Engineering and Technology

Vol. 8, Issue 7, July 2021

DOI: 10.17148/IARJSET.2021.8705

\begin{tabular}{|c|c|c|}
\hline Particular & Frequency & Percentage \\
\hline Yes & 78 & $62.4 \%$ \\
\hline No & 47 & $37.6 \%$ \\
\hline Total & 125 & $100 \%$ \\
\hline
\end{tabular}

4.7 - Table 7 shows the percentage analysis of gender issues being prevalent in schools and colleges

\begin{tabular}{|c|c|c|}
\hline Particulars & Frequency & Percentage \\
\hline Yes & 45 & $36 \%$ \\
\hline No & 49 & $39.2 \%$ \\
\hline Maybe & 31 & $24.8 \%$ \\
\hline Total & 125 & $100 \%$ \\
\hline
\end{tabular}

4.8 -Table 8 shows the percentage analysis of the satisfaction of streams offered in vocational courses.

\begin{tabular}{|c|c|c|}
\hline Particulars & Frequency & Percentage \\
\hline Yes & 45 & $36 \%$ \\
\hline No & 44 & $35.2 \%$ \\
\hline Maybe & 36 & $28.8 \%$ \\
\hline Total & 125 & $100 \%$ \\
\hline
\end{tabular}

4.9- Table 9 shows the percentage analysis of being teachers competent enough to conduct classes

\begin{tabular}{|c|c|c|}
\hline Particulars & Frequency & Percentage \\
\hline Yes & $\mathbf{3 4}$ & $\mathbf{2 7 . 2 \%}$ \\
\hline No & $\mathbf{1 3}$ & $\mathbf{1 0 . 4 \%}$ \\
\hline Maybe & $\mathbf{7 8}$ & $\mathbf{6 2 . 4 \%}$ \\
\hline Total & $\mathbf{1 2 5}$ & $\mathbf{1 0 0 \%}$ \\
\hline
\end{tabular}

Teaching methods being updated in educational institutions

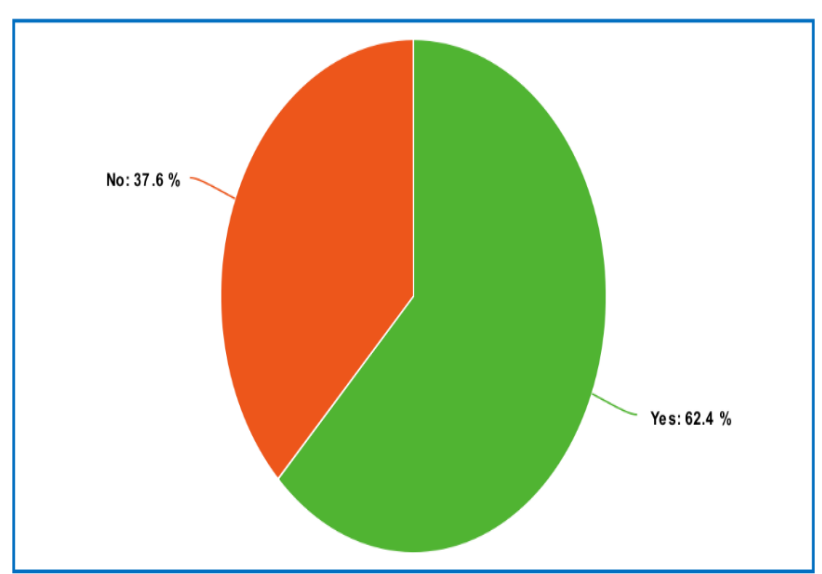

Yes $\square$ No 
International Advanced Research Journal in Science, Engineering and Technology

Vol. 8, Issue 7, July 2021

DOI: $10.17148 /$ IARJSET.2021.8705
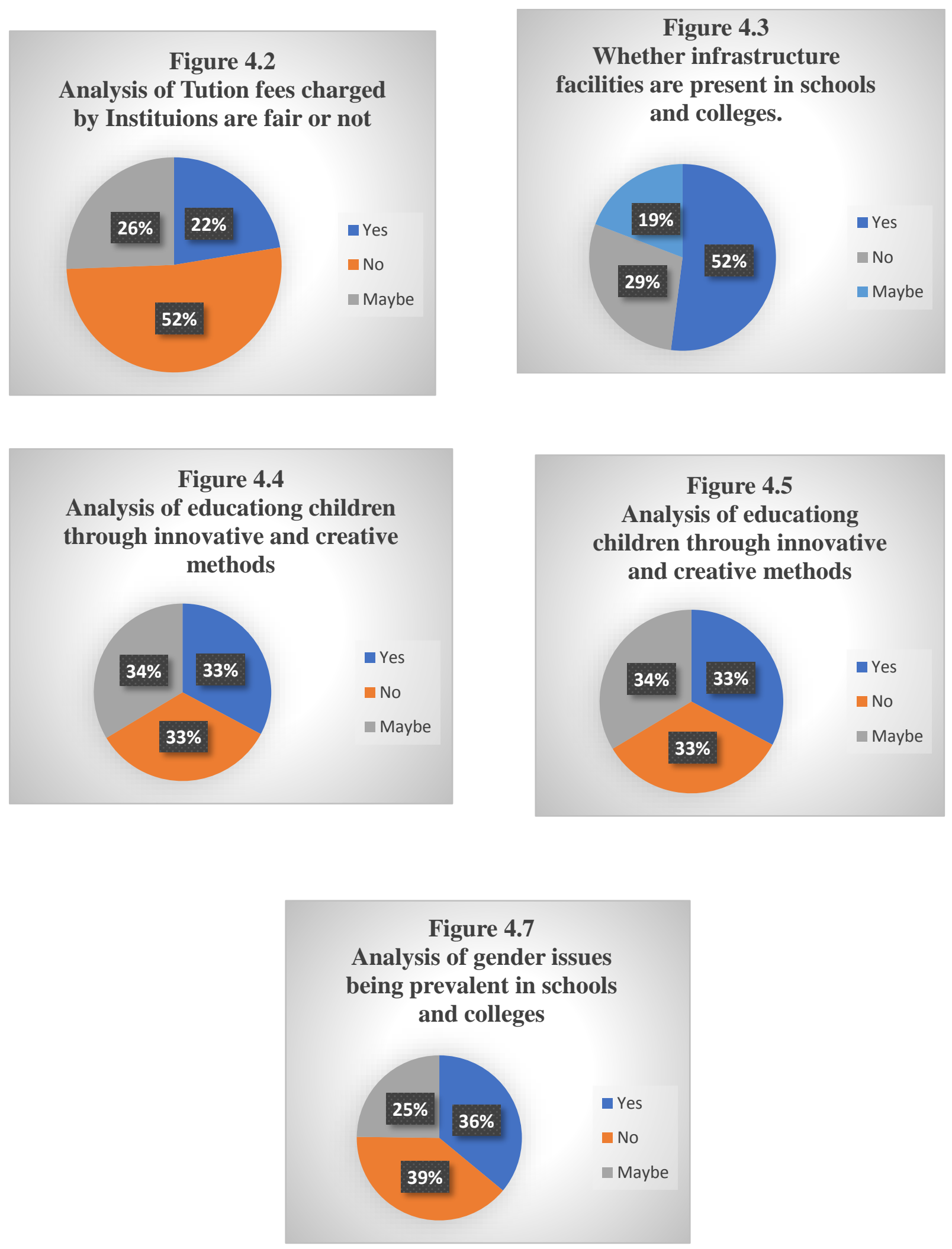

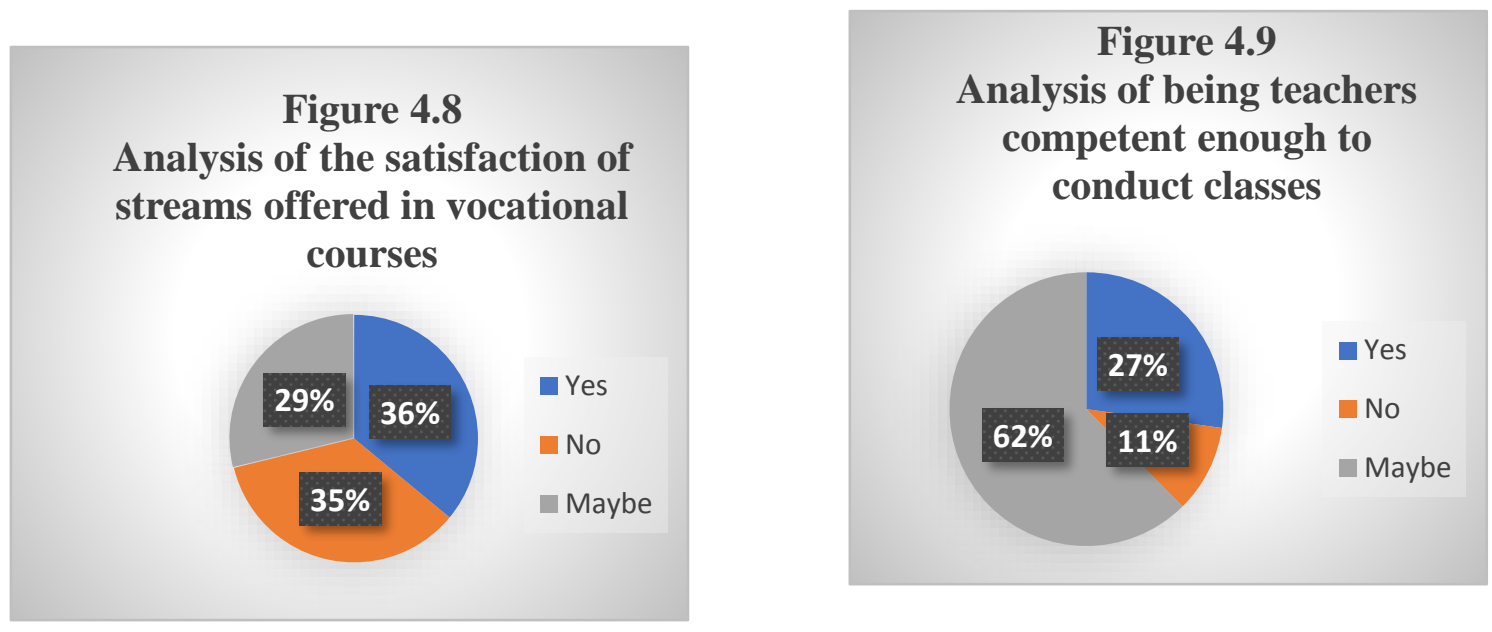

\section{FINDINGS}

- From the study it is observed that majority of respondents were from Chennai $(63.2 \%)$

- $63.2 \%$ of respondents were female and $36.8 \%$ were male respondents in the study.

- $52 \%$ of respondents have disagreed by stating that the tuition fees charged by educational institutions are not fair.

- $49.6 \%$ of respondents have rated 3 on 5 for the actual capacity against approved capacity of classrooms in an institution.

- $52 \%$ of respondents have agreed for the statement that their ward's school/college has all the necessary infrastructure facilities.

- $50.4 \%$ of respondents have rated 3 on 5 for the student- teacher ratio.

- $33.6 \%$ of respondents have disagreed and been neutral for the statement, whether a child's school is educating through creative and innovative methods to students.

- $32.8 \%$ of respondents have agreed by saying their child's school is educating them through creative and innovative methods to students.

- $43.2 \%$ of respondents have agreed and satisfied with the quality of students provided by the institutions.

- $62.4 \%$ of respondents have said yes, the teaching methods are being updated in the educational institutions.

- $31.2 \%$ of respondents have rated 5 on 5 for extra-curricular activities conducted by schools that are beneficial for students.

- $39.2 \%$ of respondents have said no for gender issues being prevalent in schools and colleges.

- $36 \%$ of respondents have said yes, gender issues are prevalent in schools and colleges.

- $38.4 \%$ of respondents have rated 4 on 5 for the level of technology used by teachers for teaching.

- $36 \%$ of respondents are satisfied with the streams in vocational courses offered to students.

- $62.4 \%$ of respondents have given a neutral answer for teachers being competent enough to conduct classes.

\section{SUGGESTIONS}

- Gender neutral education must be provided.

- Periodic training must be given to teachers which helps them to be updated.

- Infrastructure should be improved in order to provide a good learning platform for students.

- Skill based learning should be promoted.

\section{CONCLUSION:}

In the larger domain of human capital, education and skill development has a big role. Census data of 2011 on literacy gives us a quick perspective on the current status of education. However education is not just about literacy. The results of the policies can be said to be mixed and there is still a lot of room for improvement. There are various government initiatives targeting each level of the education system in India. Higher education system is given a greater focus these days. The latest update captures the need of the hour for reforming education. By doing this study, we were able to analyse the challenges and implications present in the education system of India for which suggestions are also provided but with respect to the respondents answer and current tenure. 


\section{International Advanced Research Journal in Science, Engineering and Technology}

Vol. 8, Issue 7, July 2021

\section{DOI: 10.17148/IARJSET.2021.8705}

\section{REFERENCES:}

1. Dr J.D Singh- Analysing the issues, challenges, and suggestions in higher education in India; ISBN: 978-3-8465-1753-6

2. Dr R.N Nadar- contemporary issues and challenges in the Indian education system; e-ISSN: $2278-487 \mathrm{X}$

3. Prof C Dhanapal, Mr. V. Pushpanathan -higher education in India in 2020- Issues, Challenges and suggestions towards forecast.

4. Mr. Kishore P. Bholane - Privatizing higher education: Pros and cons; ISSN: 2277-9310

5. Appu Srva,2017, Present Education system in India- group discussions ideas

6. Dr Pravat kumar Jena, Impact of covid-19 on education in India; ISSN: 0975-833X

7. MSc. Lourdes Normandi Atiaja, Dr.Rey Segundo Guerrero Proenza -Problems and challenges in higher education: MOOCS; (978-1-988652-00-9)

8. Agarwal, Pawan, higher education in India: the need for change

9. Kshitij Jethe; Aniket Hedau; Rohit Kolankar; Sahil Dhoble; Divyanshu Mataghare. "EduAR- an AR based Learning Application". International Research Journal on Advanced Science Hub, 3, Special Issue ICITCA-2021 5S, 2021, 44-47.

10. Sarbjot kaur. "Academic Achievement and Creativity among 10th Class Students". International Research Journal on Advanced Science Hub, 3 , Special Issue ICARD-2021 3S, 2021, 158-161. doi: 10.47392/irjash.2021.085

11. Yeshi Ngima; Dorjee Tsering. "Impact of COVID-19 on Education". International Research Journal on Advanced Science Hub, 2, Special Issue ICAMET 10S, 2020, 34-39. doi: 10.47392/irjash.2020.196

12. Sanyal D.K,2017,14 facts about the Indian Educational System and a remedy, https://sanyaldk.in/doing-it-in-open-source-way/14-factsaboutindian-education-system-and-a-remedy/

13. Bimlesh Yadav; Harish Kumar Tyagi. "Perception of Teachers on Implementation of CCE in the Upper Primary Schools of Delhi NCR". International Research Journal on Advanced Science Hub, 2, Special Issue ICARD 2020, 2020, 170-173. doi: 10.47392/irjash.2020.114

14. Younis Ahmad Sheikh, Vol.8, No.1, 2017, Higher Education in India: challenges and Opportunities; ISSN: 2222-1735

15. Lochan Rampal; Qurratul Aini; Sumaya Tazeen; Mirza Younus Ali Baig; Sabah Syed Nasirullah. "Integrating Emerging Cryptographic Engineering Investigation and Safety Education Complete Embedded". International Research Journal on Advanced Science Hub, 2, Special Issue ICAMET 10S, 2020, 28-33. doi: 10.47392/irjash.2020.195

16. Sandy Ariawan; Kristyana .; Nungky Nurprasetyaningsih; Rusmi .. "Virtual Discussion for Improving Motivation: A Christian Education Strategy against Covid-19 Pandemic Effect". International Research Journal on Advanced Science Hub, 2, 7, 2020, 1-5. doi: 10.47392/irjash.2020.56

17. Meenakshi Sundaram K.. "National Education Policy 1986 Vs National Education Policy 2020 - A Comparative Study". International Research Journal on Advanced Science Hub, 2, Special Issue ICAMET 10S, 2020, 127-131. doi: 10.47392/irjash.2020.210 